\title{
Construction of an immunotoxin by linking a monoclonal antibody against the human epidermal growth factor receptor and a hemolytic toxin
}

\author{
ANA D ÁVILA, CARLOS F CALDERÓN, RITA M PÉREZ, CARMEN PONS, \\ CELIA M PEREDA and ANA R ORTIZ
}

Unidad de Evaluación e Investigación de Productos Antitumorales

Instituto Nacional de Oncología y Radiobiología.

\begin{abstract}
Hybrid molecules obtained through conjugation of monoclonal antibodies and toxins constitute an approach under exploration to generate potential agents for the treatment of cancer and other diseases. A frequently employed toxic component in the construction of such immunotoxins is ricin, a plant toxin which inhibits protein synthesis at ribosomal level and so requires to be internalized by the cell. A hemolytic toxin isolated from the sea anemone Stichodactyla helianthus, which is active at the cell membrane level, was linked through a disulfide bond to the anti-epidermal growth factor receptor monoclonal antibody ior egf/r3. The resulting immunotoxin did not exhibit hemolytic activity except under reducing conditions. It was toxic for H125 cells that express the human epidermal growth factor receptor, but non-toxic for U1906 cells that do not express this receptor.
\end{abstract}

Key terms: Epidermal growth factor, epidermal growth factor receptor, hemolytic toxins, immunotoxins, monoclonal antibodies.

\section{INTRODUCTION}

Immunotoxins are bifunctional proteins, constructed by covalently linking a monoclonal antibody and a toxin, that combine the binding specificity conferred by the monoclonal antibody (Mab) with the cytotoxic ability of the toxin, allowing to selectively eliminate those cells that express the antigen recognized by the Mab.

In the last decade immunotoxins using the ricin A-chain (from Ricinus communis), abrin (from Abrus precatorius) and diphtheria toxin (from Corynebacterium diphtheriae) linked to monoclonal antibodies by chemical means have been extensively considered as an alternative in therapies against cancer, AIDS and other illnesses (Schnell et al., 2003; Zimmemann et al., 1997; Frankel and Kreitman, 2005; Engert et al., 1997; Youn et al., 2005). A second group of immunotoxins, usually called recombinant immunotoxins, is emerging in order to improve the limitations found with chemically conjugated immunotoxins. This class of immunotoxins provide enhanced therapeutic efficacy over conjugated forms and result in improved antitumor activity ( $\mathrm{Li}$ et al., 2005; Kreitman et al., 2005).

Additionally, other molecular constructions like single-chain immunotoxins using Fv Mab fragments have been tested (Posey et al., 2002; Di Paolo et al., 2003)

Toxins isolated from plants inhibit protein synthesis at ribosomal level and thus internalization of the complex by the cells is necessary (Carriere et al.,1985; Poncelet et al.,1984). Internalization is the rate-limiting step in cell killing kinetics (Youle and Neville, 1982; Jansen et al., 1985) and occurs commonly in Mabs 
directed towards leukocyte antigens, but it does not always occur, as in the case of antibodies directed against cells of epithelial origin.

In this paper we will describe the construction of a hybrid molecule using a toxin that acts on phospholipids in the cell membrane and a monoclonal antibody which recognizes the human epidermal growth factor receptor (ior egf/r3), as well as their cytotoxic activity.

\section{MATERIALS AND METHODS}

\section{Monoclonal Antibody ior egf/r3}

The monoclonal antibody ior egf/r3 Mab of injectable quality was kindly supplied by the Center of Molecular Immunology of Havana, and was generated by fusion of murine myeloma SP2/O with splenocytes obtained from mice that were immunized with a semipurified fraction of human placenta rich in the hEGF-R (Fernández et al., 1992).

The ior egf/r3 Mab is of $\operatorname{IgG}_{2 \mathrm{a}}$ subclass; it recognizes the H125 cell line, a lung adenocarcinoma that expresses hEGF-R and it doesn't recognize the U1906 cell line, a small cell lung carcinoma cell line (Suárez et al., 1997).

\section{Hemolytic toxin}

The hemolytic toxin (HT) was isolated from a saline extract of the sea anemone Stichodactyla helianthus (Stoichactis helianthus). Purification was performed by acetone precipitation, gel filtration (Sephadex G-50) and cation exchange (CMSephadex C-50) using a modification of Devlin's procedure (Devlin, 1974) designed by Avila and collaborators (Avila et al., 1989).

The HT shows an apparent molecular weight of about $18 \mathrm{kDa}$ and isoelectric point of $\mathrm{pH}$ 9.8. It exhibits a potent cytolytic activity and a slight phospholipase A2 activity (Tejuca and Alvarez, 1994). The toxin produces complete lysis of human erythrocytes at concentrations above $0.6 \mu \mathrm{g} / \mathrm{ml}$. (Avila et al., 1989).
Preparation of the conjugated ior egfl r3Mab-HT

The toxin was conjugated to the ior egf/r3 Mab using the heterobifunctional reagent $\mathrm{N}$ succinimidyl-3 (2-pyridyldithio) propionate (SPDP, Pharmacia, Uppsala, Sweden) (Carlsson et al., 1978). The modified HT and ior egf/r3 Mab were obtained by reaction with an excess of SPDP of 3 and 70, respectively. Excess SPDP was removed by gel filtration chromatography on Sephadex G-25 with phosphate-buffered saline (PBS) $0.1 \mathrm{M} \mathrm{pH} 7.5$.

The extent of thiolation was determined by the variation of the optical density at $343 \mathrm{~nm}$ due to release of pyridine 2-thione groups, after reduction with $100 \mathrm{mM}$ dithiothreitol (DTT) (Carlsson et al., 1978).

The pyridyl disulphide-HT was treated with an excess of $50 \mathrm{mM}$ DTT (40 minutes at room temperature). The removal of excess of DTT was achieved by gel filtration on Sephadex G-25. The reduced toxin was mixed with the pyridyl disulphide derivate of ior egf/r3 Mab at a 1:1 molar ratio during 72 hours, at $4^{\circ} \mathrm{C}$. The conjugate was then separated from the free toxin by gel filtration on Sephacryl S-200, eluted with PBS 0.1M pH 7.5.

The extent of conjugation was estimated following the release of pyridine 2-thione at $343 \mathrm{~nm}$, and by measuring the hemolytic activity released after reduction of the conjugate.

\section{Hemolytic activity}

The qualitative identification of hemolytic activity in the chromatographic fractions was performed by adding $20 \mu \mathrm{L}$ of the fraction to $100 \mu \mathrm{L}$ of $1 \%$ saline-washed human erythrocytes and incubating during $10 \mathrm{~min}$, at room temperature. After centrifugation $\left(500 \mathrm{~g}, 10 \mathrm{~min}, 4^{\circ} \mathrm{C}\right)$ the released hemoglobin was estimated at $540 \mathrm{~nm}$.

The quantitative assay of hemolytic activity was performed by continuously recording the decrease of optical density at $700 \mathrm{~nm}$ (Avila et al., 1989). In this assay, a hemolytic unit was defined as the amount of toxin which produces a decrease in optical density of 0.01 unit per second. Specific 
hemolytic activity was defined as units per milligram of protein $(\mathrm{HU} / \mathrm{mg})$. The analysis of the curves of the hemolysis kinetics was carried out according to the method described by Mâcek and Lebez, 1981.

Polyacrylamide gel electrophoresis (SDSPAGE):

A polyacrylamide gel electrophoresis was performed by the Laemmli method (Laemmli, 1970). The protein samples (50 $\mu \mathrm{g})$ were mixed with the same volume of sample buffer, heated at $100^{\circ} \mathrm{C}$ during 5 min and applied into a $12 \%$ polyacrylamide gel with sodium dodecylsulphate (SDS). Coomassie Blue was used for staining protein bands.

\section{Immunohistochemistry (IHQ)}

The avidin-biotin-peroxidase complex system was used (ABC-HRP, Dakopatts) in order to determine the specific recognition of the conjugated ior egf/r3 Mab in fresh samples of normal skin. (Wood and Warnke, 1981). The slides were treated with chromalum gelatin and dried, 1 hour at room temperature. The endogenous peroxidase activity was blocked with $0.3 \%$ hydrogen peroxide, $30 \mathrm{~min}$, in ethanol solution. Slides were incubated with both conjugated and free ior egf/r3 Mab. After 1 hour at room temperature, they were washed in PBS, 10 min and the biotinylated antibody and the complex was applied for $30 \mathrm{~min}$ at room temperature. The slides were washed for a further $15 \mathrm{~min}$ in $\mathrm{PBS}$ and the peroxidase reaction was developed in a freshly prepared $0.025 \%$ Diaminobenzidine (DAB) in $0.02 \%$ $\mathrm{H} 2 \mathrm{O} 2$ solution. The slides were counterstained with Mayer Hematoxylin, dehydrated, cleared and mounted in Eukitt.

\section{Radioreceptor assay}

The radioreceptor assay was performed according to the method proposed by Macías et al. (Macías et al., 1985). The human placental membrane (100 $\mu \mathrm{g}$ of protein) was incubated with ${ }^{125}$ I-EGF, labeled by the chloramine $\mathrm{T}$ method (Greenwood et al., 1963) (150-200 $\mu \mathrm{Ci} / \mu \mathrm{g})$, and unlabelled ior egf/r3 at the following concentrations: $0,1,2,5,10,20,50,100$, 200,500 and $1000 \mu \mathrm{g} / \mathrm{ml}$ at a final volume of $500 \mu \mathrm{l}$ using a binding buffer (Tris 10 $\mathrm{mM} \mathrm{pH} \mathrm{7.4,} \mathrm{BSA} 0.1 \%$ and $\mathrm{MgCl}_{2} 10 \mathrm{mM}$ ). After 1 hour at room temperature the samples were centrifuged at $500 \mathrm{~g}$ during 20 minutes and the pellet was measured for radioactivity.

\section{In vitro cytotoxicity}

Toxicity in vitro was measured on lung adenocarcinoma H125 cell line which expresses the hEGF-R and small cell lung carcinoma U1906 cell line which does not express the hEGF-R (Suárez et al., 1997). The cells were cultured in RPMI 1640 supplemented with $8 \%$ fetal calf serum. A dye-exclusion assay was performed by incubating $1 \times 10^{4} \mathrm{H} 125$ cells/well for 2,4 and 24 hours at $37{ }^{\circ} \mathrm{C}$ in the presence of the fraction to be tested and counting the percentage of the cells excluding Trypan Blue.

For the inhibition of tumor cell proliferation experiments, the tumor cells (H125 and U1906) were placed in a roundbottomed 96-well tissue culture plate $\left(1 \times 10^{4}\right.$ cells/well) and incubated overnight at $37^{\circ} \mathrm{C}$ in $5 \% \mathrm{CO}_{2}(\mathrm{~g})$. Culture medium was removed; the cells were washed with fresh medium and incubated with the samples $(100 \mu \mathrm{L})$ during 48 hours. Cells with only RPMI medium were included as controls. $\left[{ }^{3} \mathrm{H}\right]$ thymidine (1mCi/well; Amersham) was added for 7 hours at $37^{\circ} \mathrm{C}$ in $5 \% \mathrm{CO}_{2}$ (g). After trypsinization, the cells were harvested and counted. The $\left[{ }^{3} \mathrm{H}\right]$ thymidine incorporation was determined in a scintillation counter (LKB). All counts were expressed as the percentage of $\left[{ }^{3} \mathrm{H}\right]$ thymidine incorporation in test cells versus control cells.

\section{RESULTS}

Derivatization of the ior egf/r3 Mab and the toxin introduced 12 and 1 functional groups per molecule, respectively. The chromatogram of the coupling reaction mixture showed two peaks, followed by 
optical density at $280 \mathrm{~nm}$. The fractions from the first peak, corresponding to the immunotoxin, did not show hemolytic activity. However, after reducing conditions with DTT $(50 \mathrm{mM}, 40 \mathrm{~min}$, $25^{\circ} \mathrm{C}$ ) the hemolytic activity was recovered and was coincident with the first peak, near the void volume $\left(\mathrm{V}_{0}\right)$ (Fig. 1)

After the conjugation reaction, the hybrid molecule did not exhibit hemolytic activity at a concentration of $15 \mu \mathrm{g} / \mathrm{mL}$ and after reduction with DTT, the hemolytic activity was recovered. Specific hemolytic activities of the unconjugated toxin and the hybrid molecules were $0.34 \mathrm{U} / \mu \mathrm{g}$ and 0.1 $\mathrm{U} / \mu \mathrm{g}$, respectively. The estimated conjugation ratio was 3 moles of toxin per molecule of antibody.

The immunoconjugate's construction was confirmed using SDS-PAGE under reducing conditions. Molecular weights corresponding to heavy and light chains and the free toxin were observed. (Fig. 2)
The behavior of ior egf/r3 Mab linked to the toxin was similar to the free antibody. Figures $3 \mathrm{a}$ and $3 \mathrm{~b}$ show that the recognition in fresh samples of normal skin of the IT was weaker (moderate) than the free Mab at the same concentration by IHQ.

A similar result was obtained when we tested the binding of IT using a radioreceptor assay. These experiments showed that IT recognized the EGF-R in the membrane at a similar level to free ior egf/r3 Mab at 5ug (Fig. 4).

The dye-exclusion assay with Trypan Blue showed that immunotoxin was toxic on H125 cells that express the hEGF-R at all the tested times. The addition of an excess of an unconjugated ior egf/r3 Mab (20x) protected $\mathrm{H} 125$ cells from the toxicity of the immunotoxin; this protection was higher with the incubation times. The ior egf/r3 Mab was not toxic and the free toxin was toxic on H125 cells at all the tested times. (Fig. 5)

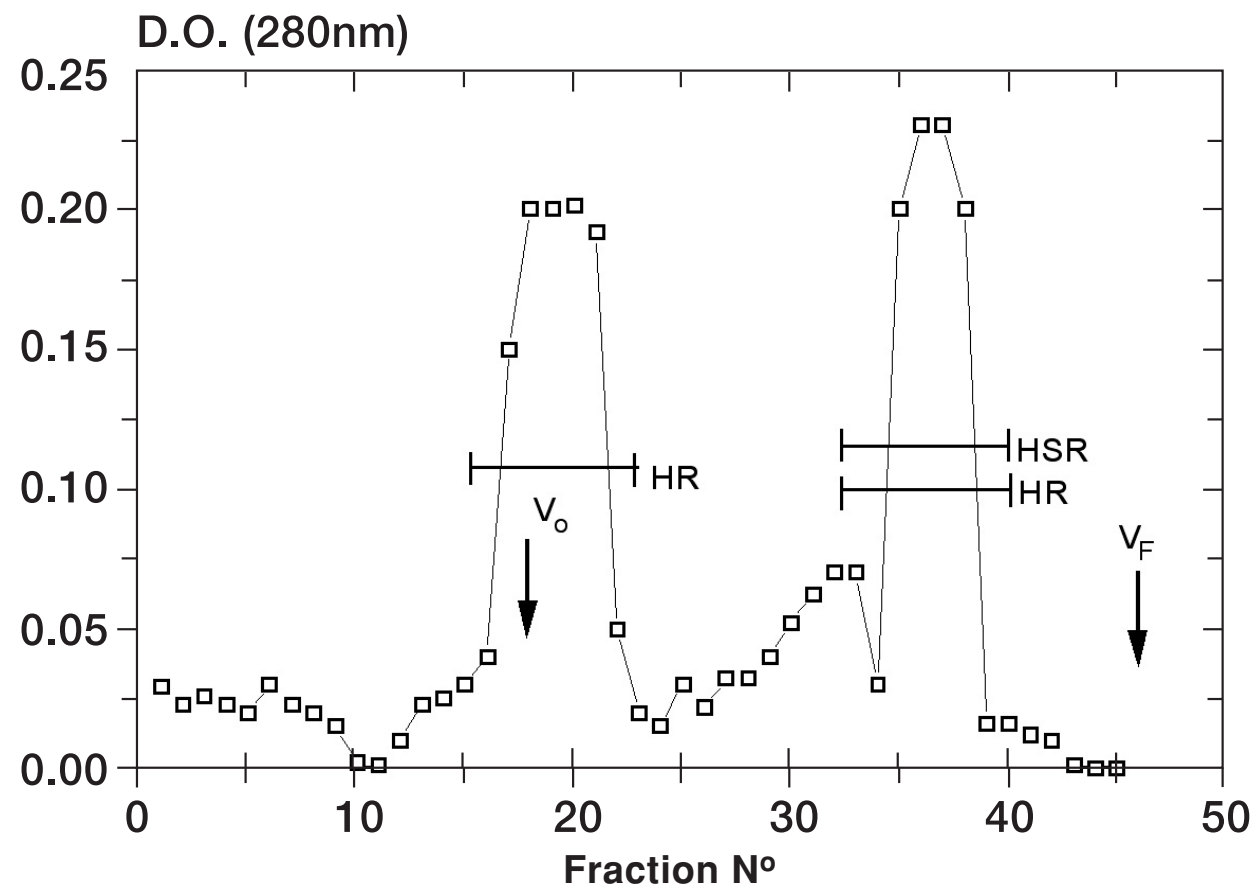

Figure 1: Elution profile on Sephacryl S-200 of the ior egf/r3 -HT immunotoxin

Column dimension: $(2.2 \times 33 \mathrm{~cm})$. Buffer elution: PBS $0.1 \mathrm{M} \mathrm{pH} 7.5$; linear flow: $30 \mathrm{~cm} / \mathrm{hr}$; fraction volume: $3 \mathrm{ml}$. Abscissa is the elution volume in $\mathrm{ml}$. Ordinate indicates the optical density at $280 \mathrm{~nm}$. Arrows indicate the void volume $\left(\mathrm{V}_{\mathrm{o}}\right)$ and the total volume of the column $\left(\mathrm{V}_{\mathrm{f}}\right)$.

HR Hemolytic activity after reducing with DTT 50mM

HSR Hemolytic activity without reducing with DTT 50mM. 


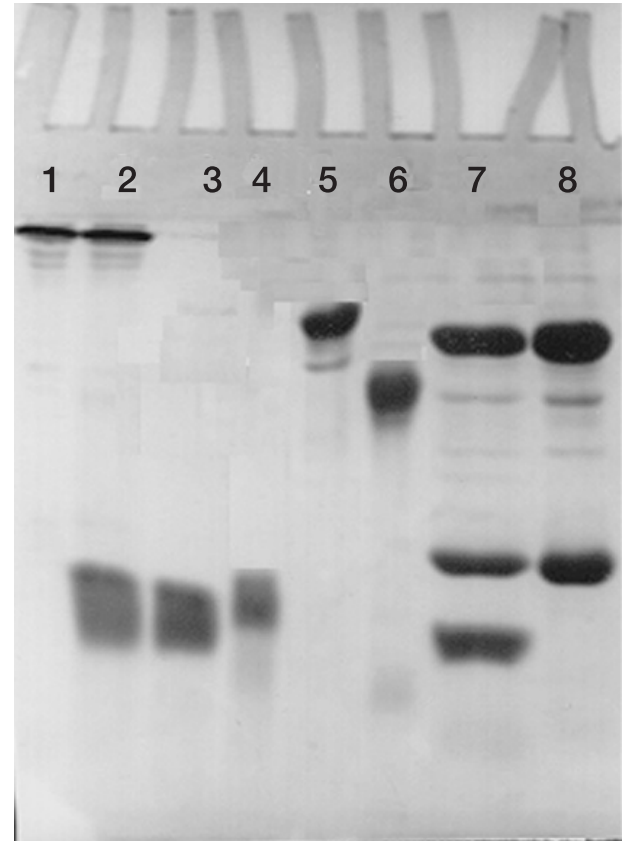

Figure 2: Electrophoresis of the immunotoxin ior egf/r3 -TH.

Lane 1: ior egf/r3 without reducing; Lane 2: Mix of free Ab and HT; Lane 3: free toxin, (18kDa); Lane 4: trypsin inhibitor (20kDa); Lane 5: BSA (67kDa); Lane 6: Ovalbumin, (43kDa); Lane 7: reduced immunotoxin; Lane 8: ior egf/r3 treated with $\beta$-mercaptoethanol.

(a)

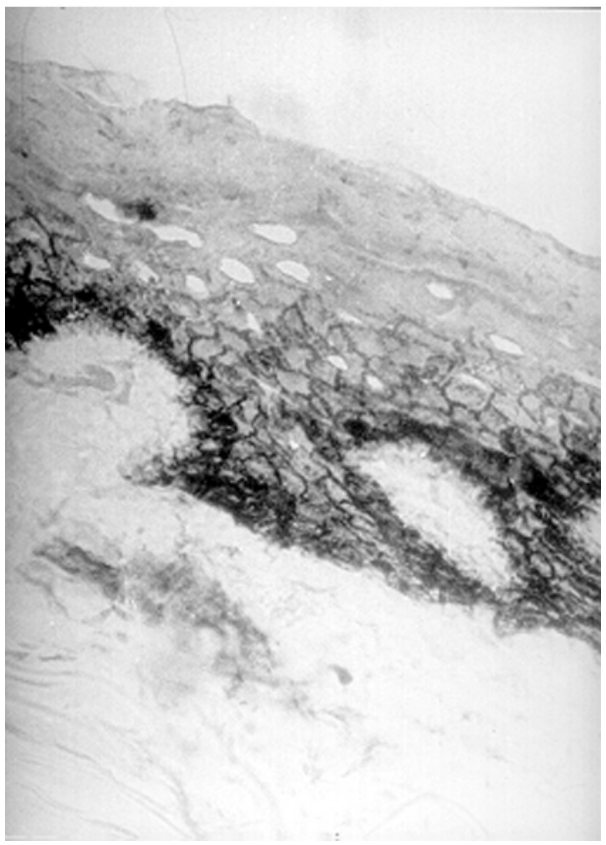

(b)

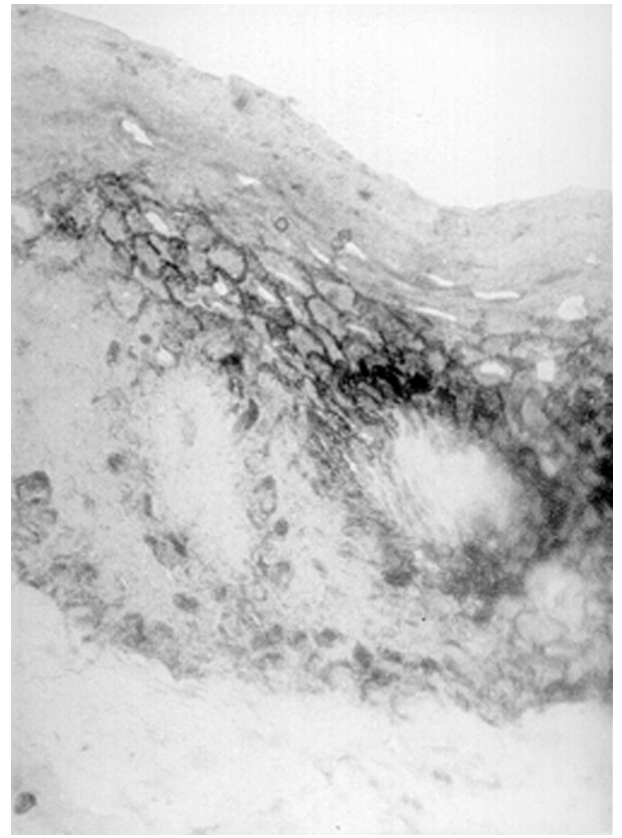

Figure 3: Immunohistochemical study of the ior egf/r3-TH immunotoxin.

Sections of fresh normal skin samples were treated with avidin-biotin-peroxidase complex system. Samples were counterstained with hematoxylin: (a) free ior egf/r3 Mab; (b) ior egf/r3 -TH immunotoxin. (x400). 


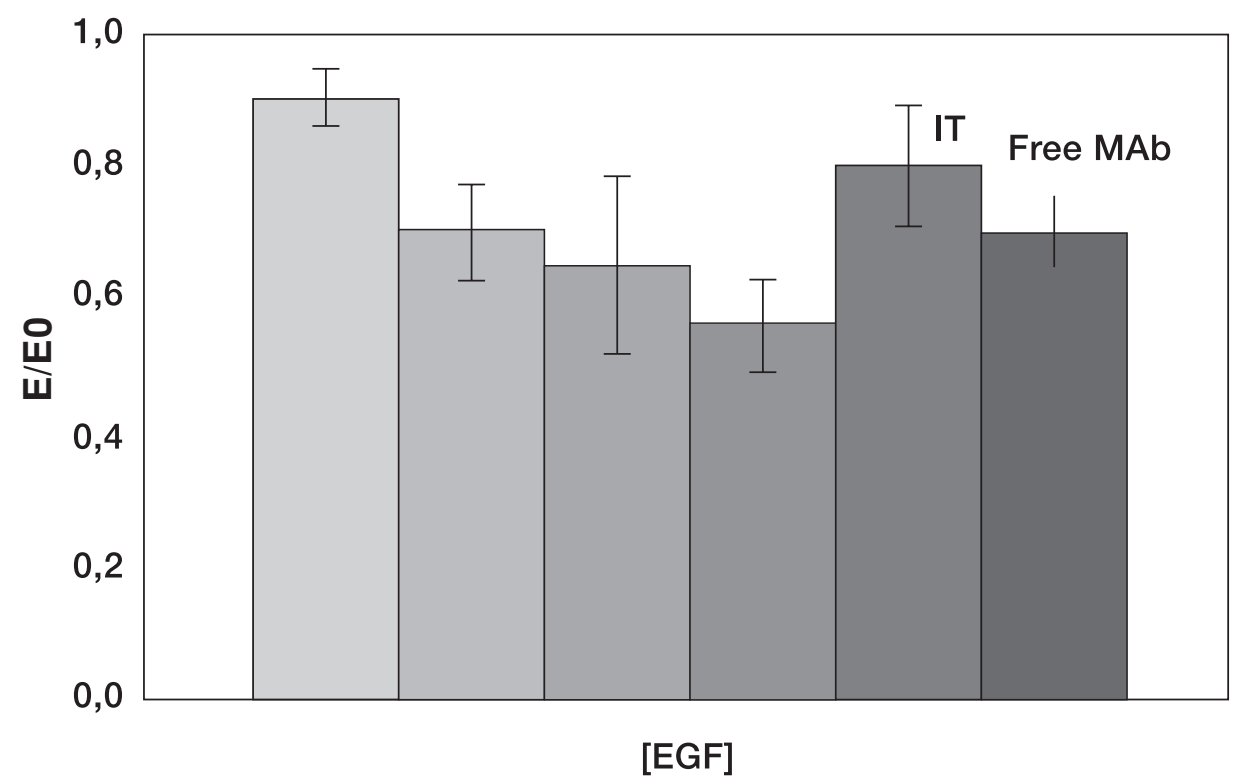

Figure 4: Binding assay of immunotoxin ior egf/r3 -TH with ${ }^{125}$ I-EGF:

$\mathbf{E}$ : specific binding of ${ }^{125}$ I-EGF at different concentrations of unlabelled ligand, EGF (expressed as CPM); Eo: Maximum specific binding (absence of unlabelled ligand 0ng/mL) Abscissa indicates the unlabelled EGF in ng [23]. Each point is the mean of triplicate measurements. Vertical bars: standard deviation.

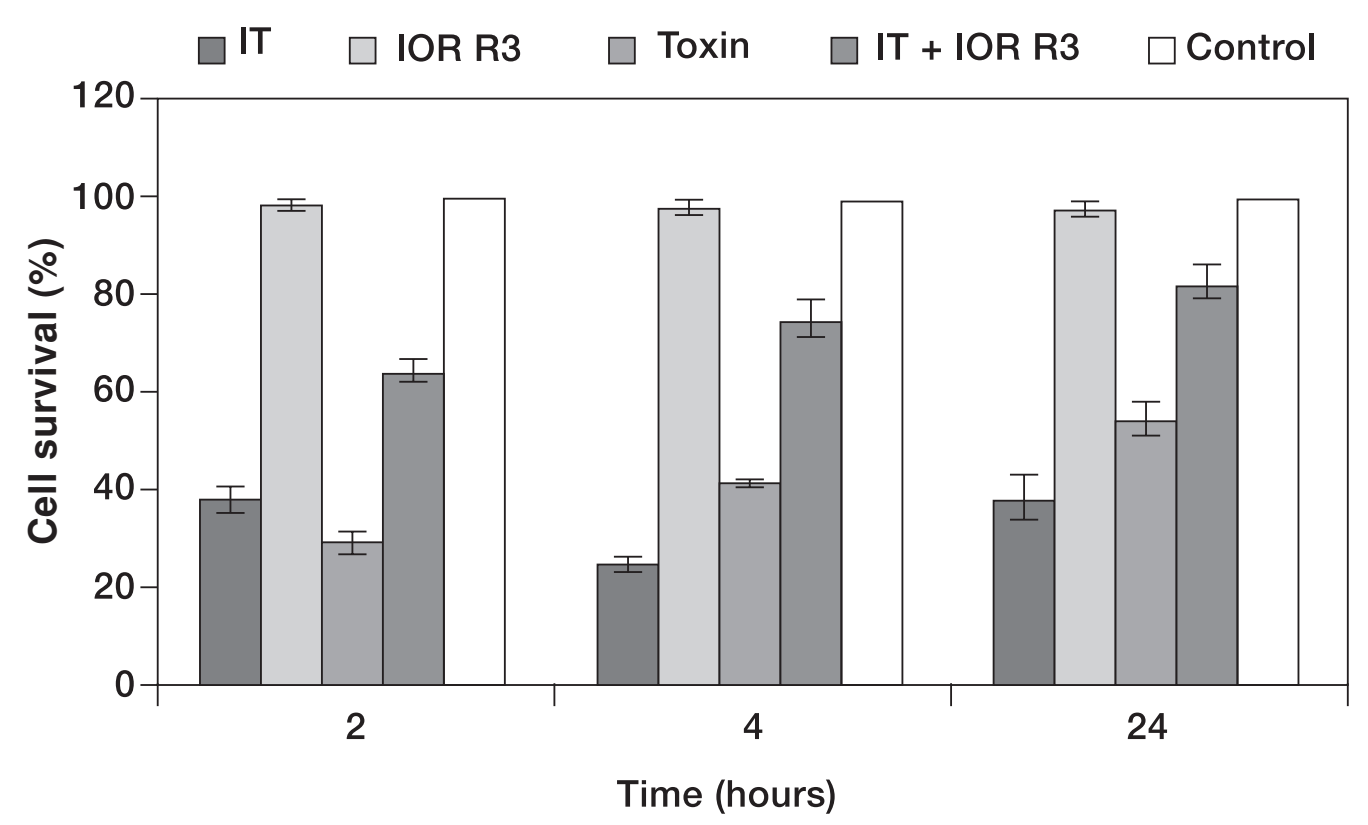

Figure 5: Cytotoxicity study in cells of H125 cell line using the Trypan Blue exclusion.

H125 cells $\left(1 \times 10^{4}\right.$ /well) were incubated for 2,4 and 24 hours at $37{ }^{\circ} \mathrm{C}$ in the presence of IT at $7 \times 10^{-8} \mathrm{M}$, free toxin and unconjugated ior egf/r3 Mab at the same concentration and IT plus an excess of antibody (20x). The cells excluding Trypan Blue were counted. Ordinate indicates the percentage of surviving cells, relative to control cultures incubated with culture media alone. Each point is the mean of triplicate measurements. Vertical bars: standard deviation. 
The inhibition of thymidine incorporation assay showed the toxicity of the immunotoxin on H125 cells at concentrations between $10^{-11}$ and $10^{-8} \mathrm{M}$. The same concentrations were not toxic for U1906 cells. Unconjugated ior egf/r3 was not toxic for either type of cell lines and free toxin was toxic for both. (Fig. 6).
This assay also confirms that an excess of unconjugated antibody prevents the toxic effect of the IT on H125 cells (Fig. 7). The difference in sensitivity between H125 and U1906 cells was abolished under reducing conditions, indicating that both types of cells were sensitive to the free toxin (Fig. 8).

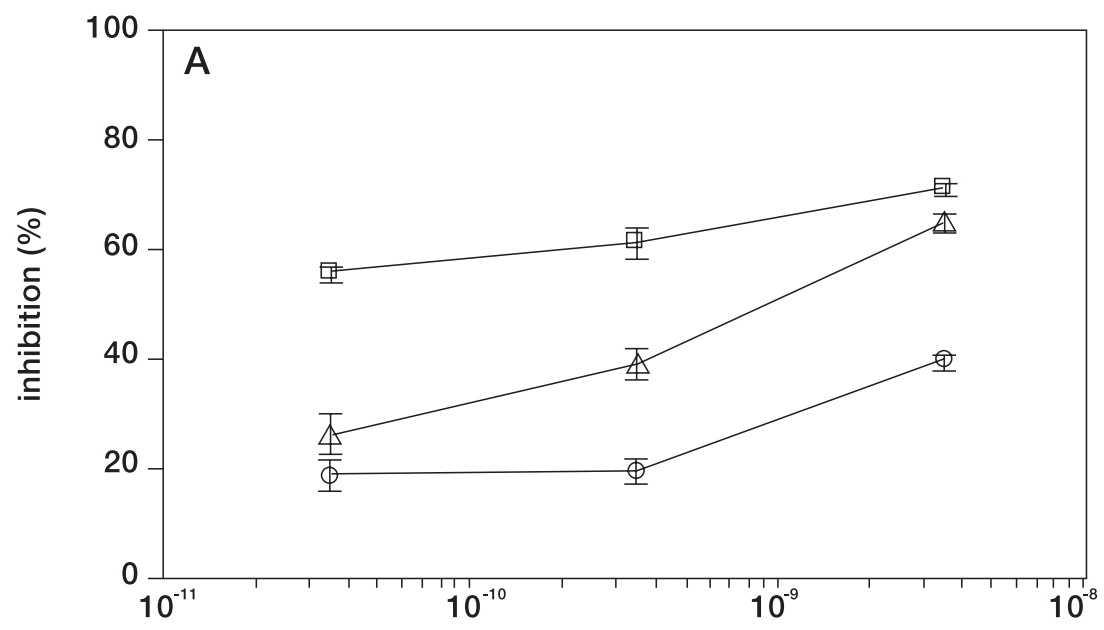

Log. Conc. (Molar)

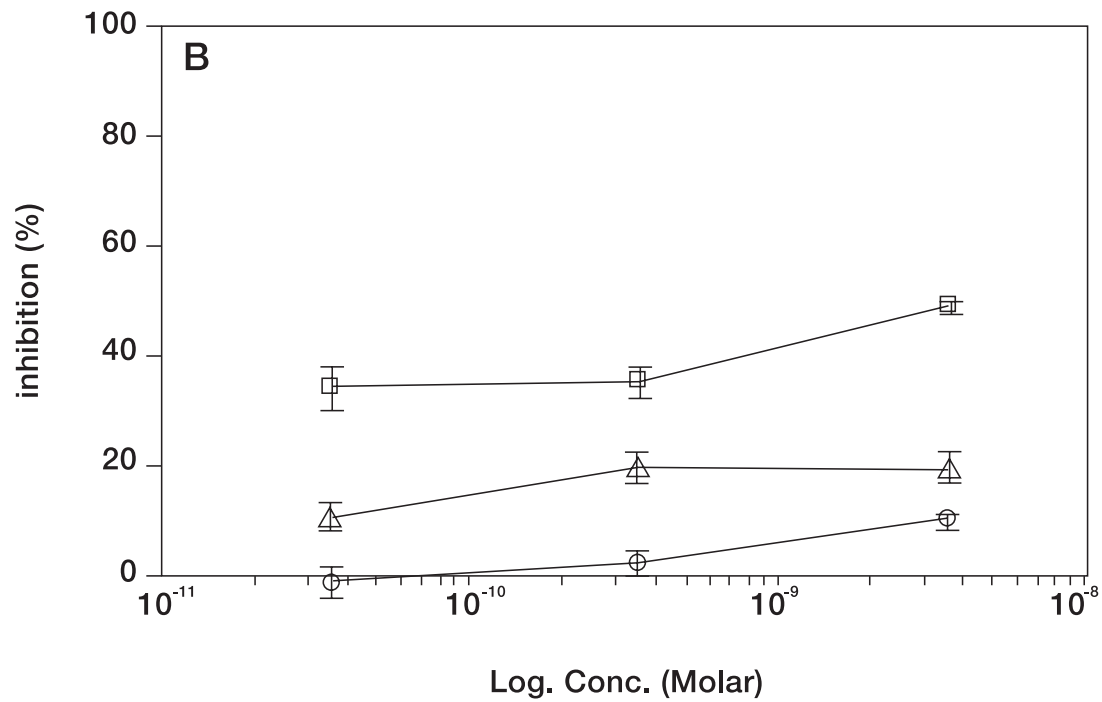

Figure 6: Cytotoxicity of the immunotoxin: ${ }^{3} \mathrm{H}$-thymidine incorporation.

$\mathrm{H} 125$ (A) and U1906 (B) were distributed in multi-well $\left(1 \times 10^{4}\right.$ cells/well) overnight at $37^{\circ} \mathrm{C}$ in $5 \%$ $\mathrm{CO}_{2}(\mathrm{~g})$. Culture medium was removed, cells were washed with fresh medium and incubated with IT $(\Delta-\Delta-\Delta)$, free toxin $(-\square-\square-\square)$ or unconjugated ior egf/r3 Mab (-O-O-O) at final concentrations indicated on the abscissa, during 48 hours. Cells with only RPMI medium were included as controls. $\left[{ }^{3} \mathrm{H}\right]$ thymidine $\left(1 \mathrm{mCi} /\right.$ well; Amersham) was added for 7 hours at $37^{\circ} \mathrm{C}$ in $5 \% \mathrm{CO}_{2}(\mathrm{~g})$. After trypsinization, cells were harvested and counted in a scintillation counter. Ordinate indicates the percentage of inhibition of $\left[{ }^{3} \mathrm{H}\right]$ thymidine incorporation in test cells versus control cells. Each point is the mean of triplicate measurements. Vertical bars: standard deviation. 


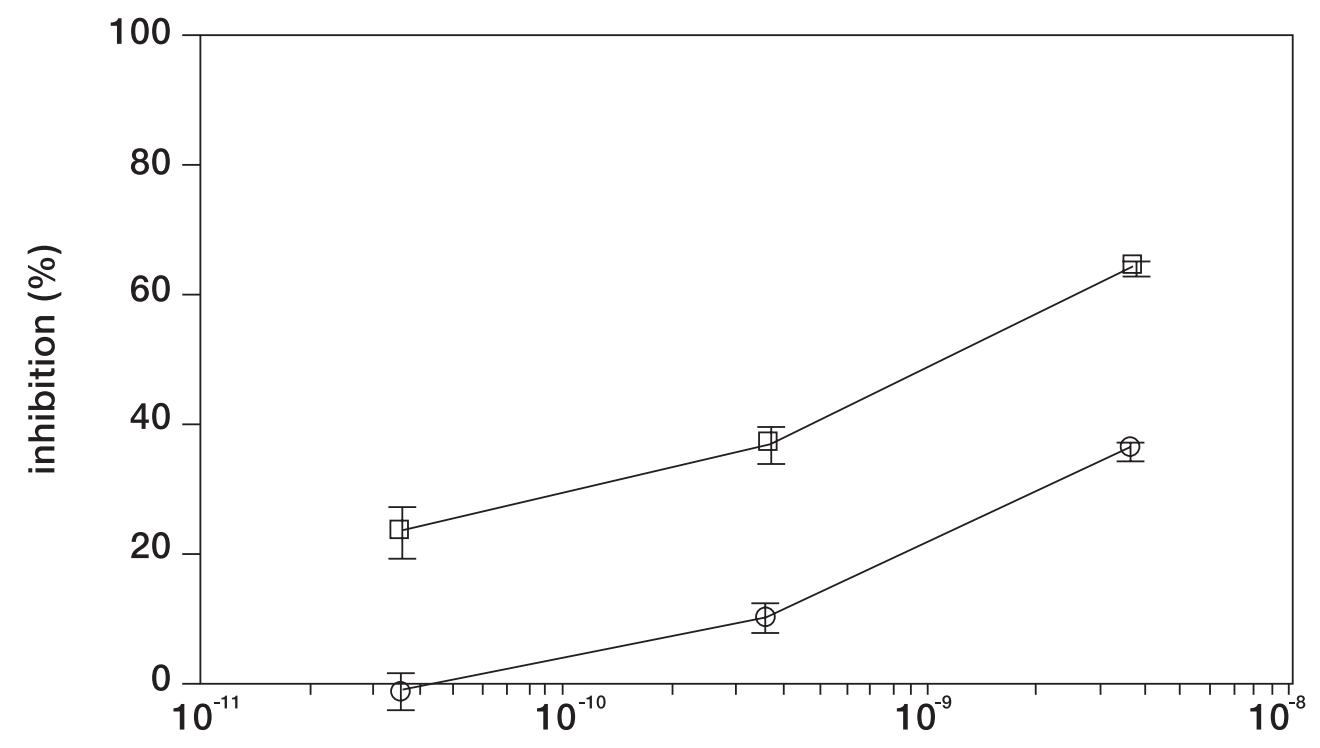

Log. Conc. (Molar)

Figure 7: Effect of unconjugated antibody excess on immunotoxin cytotoxicity.

$\mathrm{H} 125$ cells were distributed in multi-well $\left(1 \times 10^{4}\right.$ cells/well $)$ overnight at $37^{\circ} \mathrm{C}$ in $5 \% \mathrm{CO}_{2}(\mathrm{~g})$. Culture medium was removed, cells were washed with fresh serum-free RPMI-1640 medium containing the immunotoxin $(-\square-\square-\square)$ at different concentrations or the immunotoxin plus unconjugated antibody (-O-O-O). Cells with only RPMI medium were included as controls. $\left[{ }^{3} \mathrm{H}\right]$ thymidine $(1 \mathrm{mCi} /$ well; Amersham) was added for 7 hours at $37^{\circ} \mathrm{C}$ in $5 \% \mathrm{CO}_{2}(\mathrm{~g})$. After trypsinization, the cells were harvested and counted in a scintillation counter. Ordinate indicates the percentage of inhibition $\left[{ }^{3} \mathrm{H}\right]$ thymidine incorporation in test cells versus control cultures incubated with culture media alone. Each point is the mean of triplicate measurements. Vertical bars: standard deviation.

ior egf/r3 Mab, IT and hemolytic toxin were incubated at $45^{\circ} \mathrm{C}, 52^{\circ} \mathrm{C}$ and $60^{\circ} \mathrm{C}$, in order to predict the stability of IT and its components, at $4^{\circ} \mathrm{C}$. Biological activities of the IT, unconjugated antibody and free toxin were tested at several times to verify the effect of temperature. We found that the IT might lose half of its activity after 1-1.5 years stored at $4^{\circ} \mathrm{C}$ (Data not shown) based on Arrhenius's kinetics. (Frost and Pearson, 1968).

\section{DISCUSSION}

The results show that it is possible to link ior egf/r3 Mab to the hemolytic toxin obtained from $S$. helianthus by means of disulphide linkage provided by the heterobifunctional reagent SPDP. The properties of the immunotoxin built by this method are coincident with those of similar molecules that have been synthesized previously (Avila et al., 1988; Avila et al.,1989; Beutler, 1971).

The most interesting property of the IT is the loss of hemolytic activity which is recovered under reducing conditions when the toxic component is released from the conjugate. It is very important for in vivo experiments in the future. The lack of the hemolytic activity might be due to some steric hindrance introduced by the larger immunoglobulin molecule. The in vivo reduction of the hybrid molecule implies a loss of specificity and the appearance of the toxic effect, however it is demonstrated that in mammals there is no important system of reduction of disulphide bridges in plasma (Yanai et al., 1991). Nevertheless, the stability of the disulphide bridge should be carefully checked in vivo before carrying out any clinical trials. Recombinant immunotoxins may circumvent this problem 


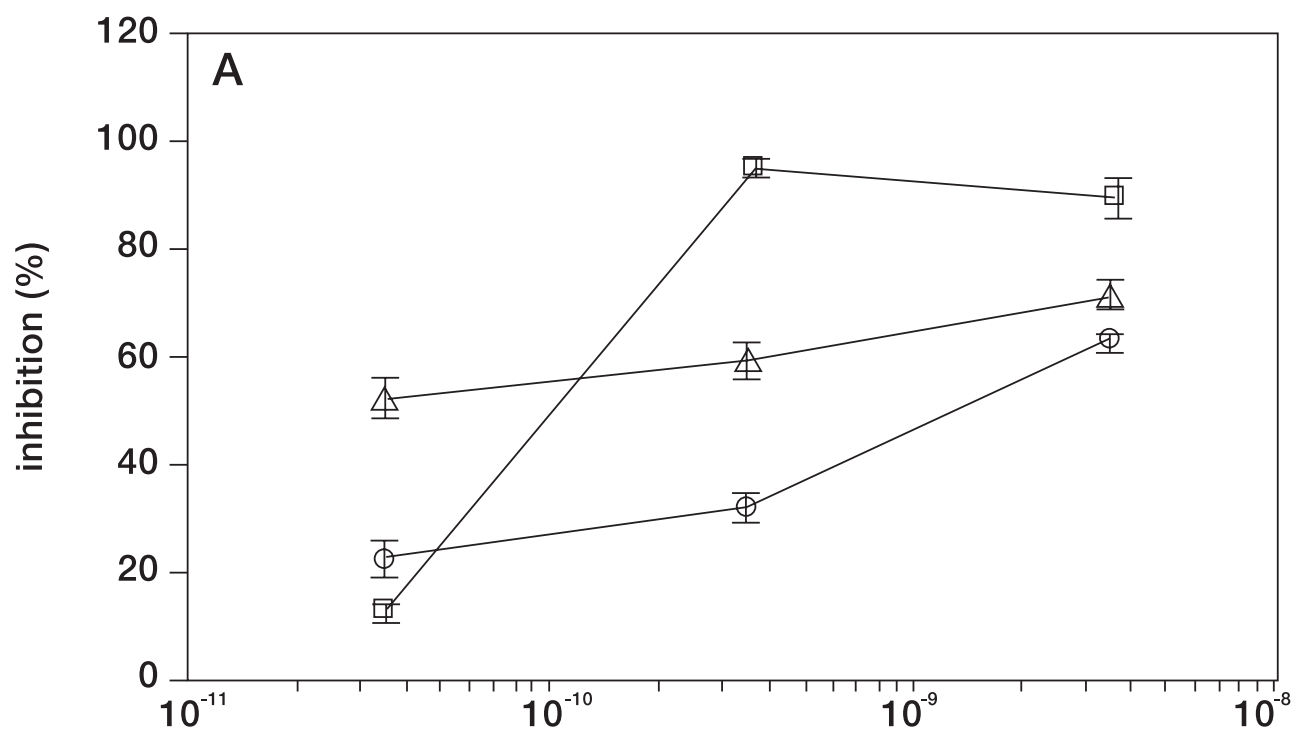

Log. Conc. (Molar)

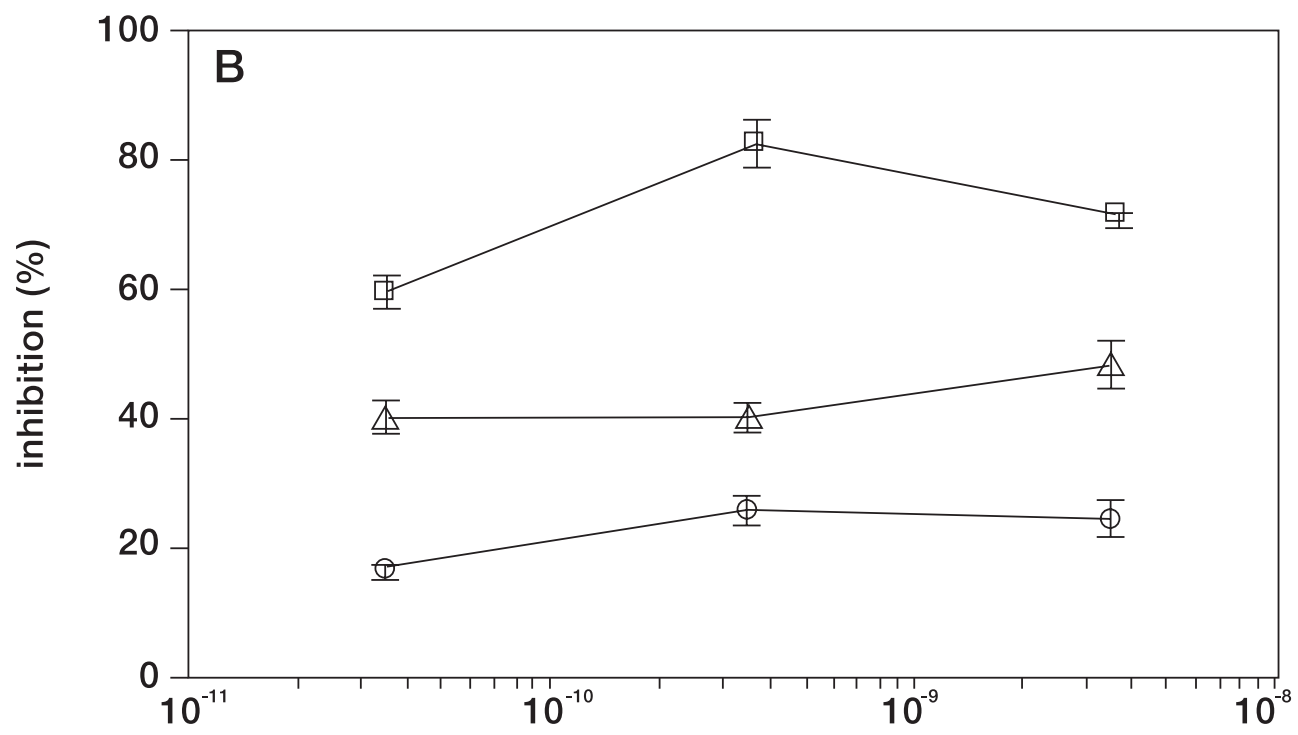

Log. Conc. (Molar)

Figure 8: Effect of IT under reducing conditions: ${ }^{3} \mathrm{H}$-thymidine incorporation.

H125 (A) and U1905 (B) cell lines were distributed in multi-well plates at $1 \times 10^{4}$ cells/well and incubated with immunotoxin (-O-O-O), free toxin $(\Delta-\Delta-\Delta)$ and immunotoxin plus DTT (- $\square-\square-\square$ ) at concentrations indicated on the abscissa. After incubation at $37^{\circ} \mathrm{C}$ for 48 hours cells with only RPMI medium were included as controls. $\left[{ }^{3} \mathrm{H}\right]$ thymidine $(1 \mathrm{mCi} /$ well; Amersham $)$ was added for 7 hours at $37^{\circ} \mathrm{C}$ in $5 \% \mathrm{CO}_{2}(\mathrm{~g})$. After trypsinization, the cells were harvested and counted in a scintillation counter. Ordinate indicates the percentage of inhibition of $\left[{ }^{3} \mathrm{H}\right]$ thymidine incorporation in test cells versus control cultures incubated with culture medium alone. Each point is the mean of triplicate measurements. Vertical bars: standard deviation. 
(Fitzgerald and Pastan I, 1996; Kreitman et al., 2005)

The immunohistochemistry and competition with ${ }^{125}$ I-EGF assays indicate that the MAb retained its biological activity in the immunotoxin. Nevertheless, we found a slight decrease in the recognition of the hEGF-R by the immunotoxin. It might be due to some steric hindrance for the complex ior egf/r3-HT.

Due to the higher expression of the EGF-R in H125 cell line, the immunotoxin was more toxic on this type of cells than on U1906. The cytotoxic activity of the HT in the complex is targeted by the kinetics of binding between ior egf/r3 Mab to its hEGF-R, therefore the activity depends on the quantity of available receptors and the binding reaction rate.

The protective effect of an excess of unconjugated Mab in H125 cell line treated with the immunotoxin, is the result of the competition for the hEGF-R by both molecules. The binding of the free MAb to the receptor increases with time. According to the kinetic pattern proposed by Yanai et at. (1991) for EGF-hEGF-R union reaction, there is a probability of reversibility in this reaction. All this could be the cause of increment in cell survival for incubation periods greater than 4 hours (Fig. 5).

The immunotoxin inhibited cellular proliferation after exposure to reducing conditions in a similar way as free HT in H125 and U1906 cell lines. Therefore the toxicity effects observed in H125 cell line and non-toxicity effects for U1906 cell line when they were exposed to IT, the protective effect observed when there is an excess of free ior egf/r3 Mab and the loss of differential toxicity when the IT is exposed to reducing conditions all indicate that the toxic effect of the conjugate on these cell lines is through ior egf/r3 Mab moiety of IT.

The preliminary study about the thermostability of ior egf/r3 - HT immunotoxin predicted that half of the biological activity (recognizing MAb and toxin hemolytic abilities) would be lost after 1.5 years storing at $4{ }^{\circ} \mathrm{C}$. Although these results are a rough estimation, they showed that the ior egf/r3 -HT is a stable molecule (data not shown). This is an important issue for patient applications in general.

Lung adenocarcinoma is a disease resistant to chemotherapy and radiotherapy treatments. The selective toxicity of the immunotoxin on H125 cell line (lung adenocarcinoma) makes this molecule an interesting alternative for the treatment of this kind of lung cancer.

In most cases, toxins such as ricin and its subunits, have been coupled to MAbs and internalized in cells order to inhibit intracellular protein synthesis. We have presented here an immunotoxin involving a hemolytic toxin that is active on the cell membrane as a system which does not need internalization into cells. This feature gives an advantage over ricin-immunotoxins and could be a good choice for building immunotoxins using antibodies that target antigens which experience no endocytic internalization, as it happens with many kinds of carcinoma-antigens like lung and head and neck cancer.

\section{REFERENCES}

ÁVILA AD, MATEO DE ACOSTA C and LAGE A (1989) A carcinoembryonic antigen-directed immunotoxin built by linking a monoclonal antibody to hemolytic toxin. Int J Cancer 43: 926

ÁVILA AD, MATEO DE ACOSTA C y LAGE A (1989) Purificación de una toxina a partir de la anémona de mar Stoichactis helianthus. Revista Cubana Oncología 5(1-2): 107-121

ÁVILA AD, MATEO DE ACOSTA C and LAGE A (1988) A new immunotoxin built by linking a hemolytic toxin to a monoclonal antibody specific for immature $\mathrm{T}$ lymphocytes. Int. J Cancer 42: 568

BEUTLER E. Red cell metabolism. In: Manual of Biochemical Methods. Grune and Stratton, New York and London, 1971

CARLSSON J, DREVIN H and AXEN R (1978) Protein thiolation and reversible protein-protein conjugation. $\mathrm{N}$-succinimidyl 3-(2-pyridyldithio) propionate, a new heterobifunctional reagent. Biochem J 173: 723-73

CARRIERE D, CASELLAS P, RICHER G, GROS P, and JANSEN FK (1985) Endocytosis of an antibody ricin A-chain conjugate (immuno-A toxin) adsorbed on colloidal gold. Effect of ammonium chloride and monensin. Exp Cell Res 156: 327-340

DEVLIN JP (1974) Isolation and partial purificacion of hemolytic toxin from sea anemone Stoichactis helianthus. Journal of Pharmaceutical Science 1974; 63(9): 1478-1480

DI PAOLO C, WILLUDA J, KUBETZKO S, LAUFFER I, TSCHUDI D, WAIBEL R, PLUCKTHUN A, STAHEL RA，ZANGEMEISTER-WITTKE U (2003) A recombinant immunotoxin derived from a humanized epithelial cell adhesion molecule-specific single-chain 
antibody fragment has potent and selective antitumor activity. Clin Cancer Res 9: 2837-48

ENGERT A, DIEHL V, SCHNELL R, RADSZUHN A, HATWING MT, DRILLICH S, SCHON G, BOHLEN H, HANSMANN ML, BARTH S, SCHENDLER J, GHETIE V, UHR J, VITETTA E (1997) A phase I study of an anti-CD25 ricin- A chain immunotoxins (RFT5-SMPT-dgA) in patients with refractory Hodgkin's lymphoma. Blood 89: 403-410

FERNÁNDEZ A, SPITEZR E, PÉREZ R, BOEHMER SD, ECKERT K (1992) Sistema de producción del anticuerpo monoclonal IOR R3. J. Cell Biochem 49: $157-167$

FITZGERALD D, PASTAN I (1996) Recombinant Immunotoxins. Journal of Controlled Research 39: 261-265

FRANKEL AE, KREITMAN RJ (2005) CLL immunotoxins. Leuk Res 29: 985-986

GREENWOOD FC, HUNTER WM and GLOVER JS (1963) The preparation of ${ }^{131}$ I-labelled human growth hormone of high specific radioactivity. Biochem J 89: $114-123$

JANSEN FK, BLYTHMAN HE, BOURRIE B, CARRIERE D, CASELLAS P, DUSSOSSOYS D, GROS O, LAURENT JC, LIANCE MC, PONCELET P, RICHER G, and VIDAL H (1985) Significance of kinetics of immunotoxin cytotoxicity. In: G. Gregoradis, G. Poste, G. Senior and A. Trover (eds). Receptor-mediated targeting of drugs. Plenum, New York

KREITMAN RJ, SQUIRES DR, STETLER-STEVENSON M, NOEL P, FRITZGERALD DJ, WILSON WH, PASTAN I (2005) Phase I trial recombinant immunotoxin RFB4(dsFv)-PE38 (BL22) in patients with B-cell malignancies. J Clin Onco 23: 6719-6729

LAEMMLI UK (1970) Clevage of structural protein during the assembly of the head of bacteriophage T4. Nature 227: 680-685

LI Z, YU T, ZHAO P, MA, J (2005) Immunotoxins and cancer therapy. Cell Mol Immunol 2: 106-112

MACEK P and LEBEZ D (1981) Kinetics of hemolysis induced by equinatoxin, a cytolytic toxin from the sea anemone. Actina equina. Effect of some ions and $\mathrm{pH}$. Toxicon 19: 233

MACIAS A, PÉREZ R, LAGE A (1985) Estudios sobre el factor de crecimiento epidérmico. II. Desarrollo de un radioreceptor análisis para la determinaciones de cantidades picomolares. Interferón y Biotecnología 2: $115-127$
PONCELET P, BLYTHMAN HE, CARRIERE D, CASELLAS P, DUSSOSSOYS D, GROS O, GROS P, JANSEN FK, LAURENT JC, LIANCE MC, VIDAL H, and VOISIN GA (1984) Present potential of immunotoxins. Bohring Inst Mitt 74: 94-100

POSEY JA, KHAZAELI MB, BOOKMAN MA, NOWROUZI A, GRIZZLE WE et al., A phase I trial of the single-chain immunotoxin SGN-10 (BR96 sFvPE40) in patients with advanced solid tumors. Clin Cancer Res 8: 3092-3099

SCHNELL R, BORCHMANN P, STAAK JO, SCHINDLER J, GHETIE V, VITETTA ES, ENGERT A (2003) Clinical evaluation of ricin A-chain immunotoxins in patients with Hodgkin's lymphoma. Ann Oncol 14: 729-736

SUAREZ PESTANA E, GREOSER U, SÁNCHEZ B, FERNÁNDEZ LE, LAGE A, PÉREZ R, BÖHMER FD (1997) Growth inhibition of human lung adenocarcinoma cells by antibodies against epidermal growht factor receptor and ganglioside $\mathrm{GM}_{3}$. Br J Cancer 75: 213-220

TEJUCA M, ALVAREZ C (1994) Mecanismo hemolítico de dos citolisinas purificadas de Stichodactyla helianthus, 1994, $3^{\text {er }}$ Congreso de Ciencias del Mar, Cuba' '94

WOOD GS, WARNKE R (1981) Suppression of endogenous avidin binding activity in tissues and its relevance to biotin-avidin detection systems. J Histochem Cytochem 29: 1196-1204

YANAI S, SUGIYAMA Y, CHOOL KIM D, IGA T, FUWA T, HANANO M (1991) Kinetic analysis of receptor-mediated endocytosis of epidermal growth factor by isolated rat hepatocytes. Am J Physiol 260: C457-C467

YOULE R, and NEVILLE DM Jr (1982) Kinetics of protein synthesis inactivation by ricin-anti-Thy 1.1 monoclonal antibody hybrid. J Biol Chem 257: 15981601

YOUN YS, NA DH, YOO SD, SONG SC, LEE KC (2005) Carbohydrate-specifically polyethylene glycolmodified ricin A-chain with improved therapeutic potential. Int J Biochem Cell Biol 37: 1525-1533

ZIMMERMANN S, WELS W, FROESCH BA, GERSTMAYER B, STACHEL RA, ZANGEMEISTERWITTKE U (1997) A novel immunotoxin recognizing the epithelial glycoprotein-2 has potent antitumoral activity on chemotherapy- resistant lung cancer. Cancer Immunol Immunother 44: 1-9 
